HEDL-TME 77-31
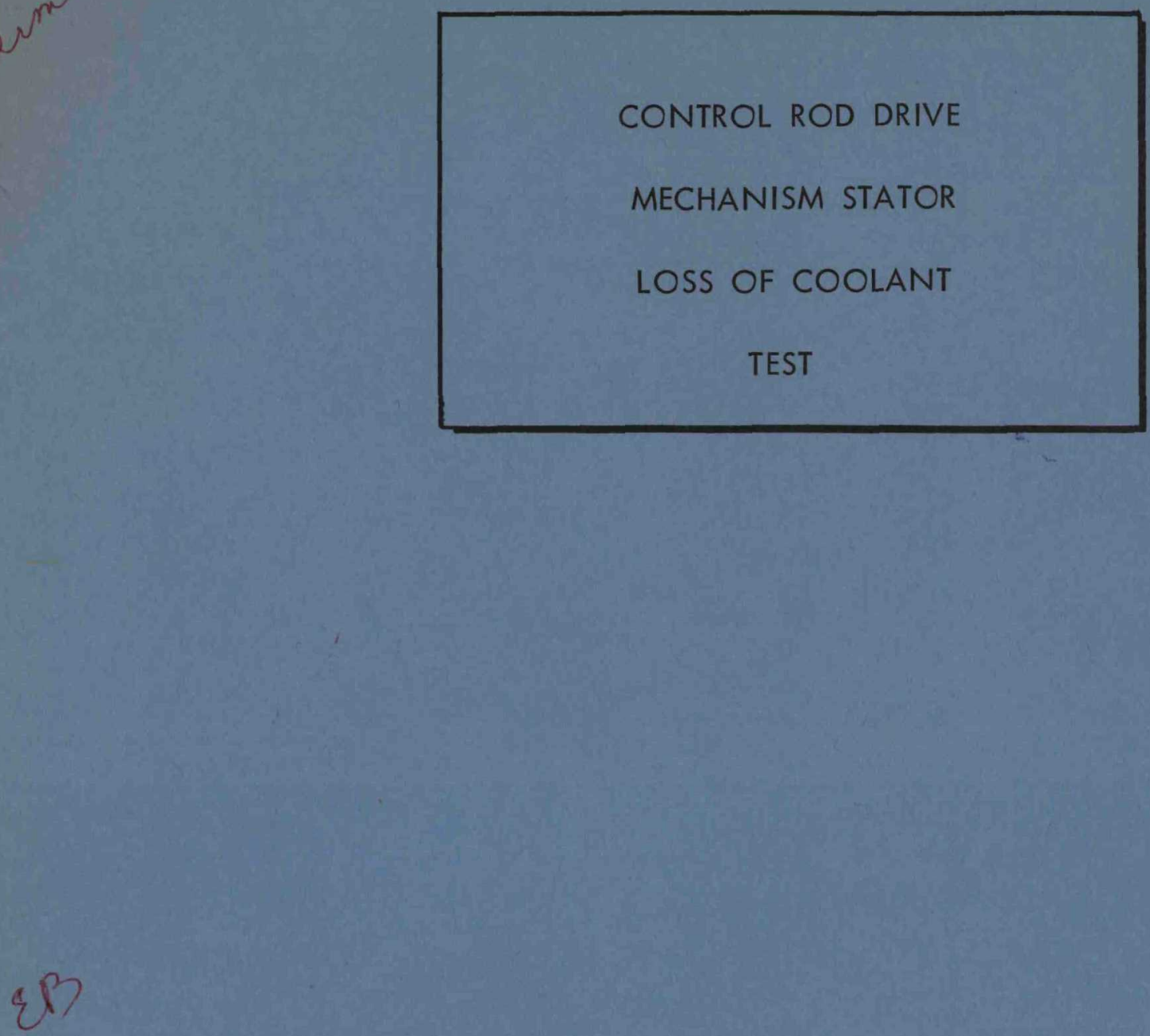

(

$19+p_{-}$

CONTROL ROD DRIVE

MECHANISM STATOR

LOSS OF COOLANT

TEST

HANFORD ENGINEERING DEVELOPMENT LABORATORY

P.0. Box $1970 \quad$ Richland, WA 99352

Operated by Westinghouse Hanford Company

A Subsidiary of Westinghouse Electric Corporation

Prepared for the U.S. Energy Research and Development

Administration under Contract No. EY-76-C-14-2170 


\section{DISCLAIMER}

This report was prepared as an account of work sponsored by an agency of the United States Government. Neither the United States Government nor any agency Thereof, nor any of their employees, makes any warranty, express or implied, or assumes any legal liability or responsibility for the accuracy, completeness, or usefulness of any information, apparatus, product, or process disclosed, or represents that its use would not infringe privately owned rights. Reference herein to any specific commercial product, process, or service by trade name, trademark, manufacturer, or otherwise does not necessarily constitute or imply its endorsement, recommendation, or favoring by the United States Government or any agency thereof. The views and opinions of authors expressed herein do not necessarily state or reflect those of the United States Government or any agency thereof. 


\section{DISCLAIMER}

Portions of this document may be illegible in electronic image products. Images are produced from the best available original document. 



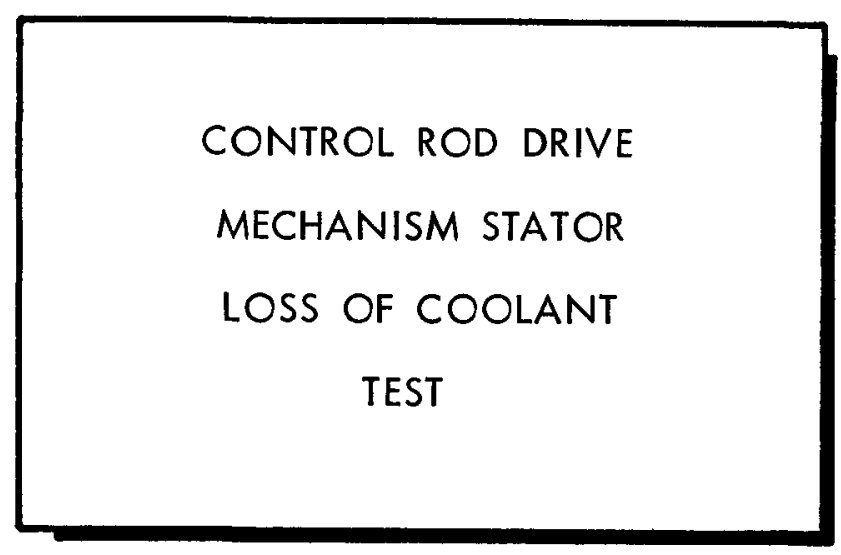

April 1977

\begin{tabular}{|c|c|c|}
\hline $\begin{array}{l}\text { Operated by the } \\
\text { Westinghouse } \\
\text { Hanford Company }\end{array}$ & $\begin{array}{l}\text { A Subsidiary of } \\
\text { Westinghouse Electric } \\
\text { Corporation }\end{array}$ & $\begin{array}{l}\text { for the United States } \\
\text { Energy Research and } \\
\text { Development Administration } \\
\text { Contract No EY-76.C 14.2170 }\end{array}$ \\
\hline
\end{tabular}

This report was prepared as an account of work sponsored by the United States Government. Neither the United States nor the United States Energy Research and Development Administration, nor any of their employees, nor any of their contractors, subcontractors, or theis employess, makes lay lisbilty of responsibility for the accuracy, completeness or usefulness of any information, apparatus, product or process disclosed, or represents that its use would no infringe privately owned rights. 


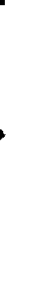




\title{
CONTROL ROD DRIVE MECHANISM \\ STATOR LOSS OF COOLANT TEST
}

\author{
Leland Besel \\ and \\ Robert Ibatuan
}

\begin{abstract}
$\underline{\text { ABSTRACT }}$
This report documents the stator loss of coolant test conducted at HEDL on the lead unit Control Rod Drive Mechanism (CRDM) in February, 1977. The purpose of the test was to demonstrate scrom capability of the CRDM with an uncooled stator and to obtain a time versus temperature curve of an uncooled stator under power. Brief descriptions of the test, hardware used, and results obtained are presented in the report. The test demonstrated that the CRDM could be successfully scrommed with no anomalies in both the two-phase and three-phase stator winding hold conditions after the respective equilibrium stator temperatures had been obtained with no stator coolant.
\end{abstract}




\section{CONTENTS}

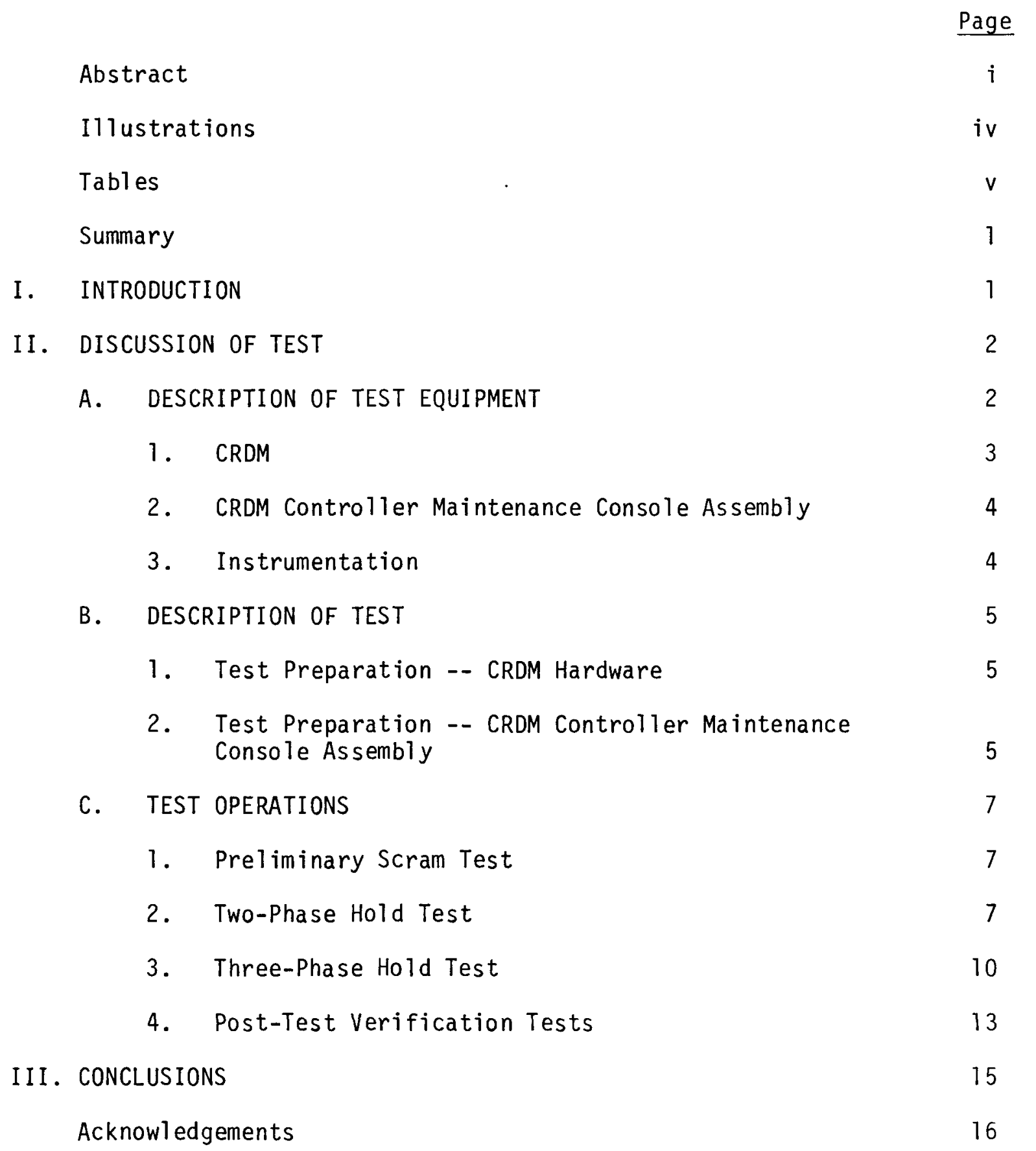




\section{ILLUSTRATIONS}

FIGURE

PAGE

1 CRDM Stator Temperatures vs Time -- 2-Phase Hold

2 CRDM Stator Temperatures vs Time -- 3-Phase Hold

18

3 Control Rod Drive Mechanism (CRDM) Configuration -Nomenclature

4 CRDM Controller Maintenance Console 20

$5 \quad$ Stator Loss of Coolant Test Configuration 27

6 CRDM Stator Temperatures vs Time -- Preliminary Scram and 2-Phase Hold

7 CRDM Stator, 2-Phase, Voltage and Current vs Time 23

8 CRDM Stator Temperatures vs Time -- First Latch Attempt 3-Phase Hold

9 CRDM Stator, 3-Phase, Voltage and Current vs Time 25

10 CRDM Stator Temperatures vs Time -- CRDM Leadscrew Cycle Test

11 Position Detector Assembly 27

12 Position Detector Assembly 28

13 CRDM Stator As sembly 29

14 CRDM Stator Assembly 30

15 CRDM Motor Tube Assembly 31 


\section{TABLES}

TABLE

PAGE

1 Thermocouple Resistance Measurements and Recorder Channel Identification

2 Temperature Readings for CRDM Stator 2-Phase Hold Test

3 Temperature Readings for CRDM Stator 3-Phase Hold Test

4 CRDM External Temperatures During Stator Loss of Coolant Tests

5 CRDM Stator Temperatures During CRDM Leadscrew Cycle Test 
CONTROL ROD DRIVE MECHANISM

STATOR LOSS OF COOLANT TEST

\section{SUMMARY}

The Control Rod Mechanism stator loss of coolant test was performed by Westinghouse-Hanford Company in the High Temperature Sodium Facility (HTSF) at the Hanford Engineering Development Laboratory (HEDL) Richland, Washington in February 1977. The primary test objective was to demonstrate the scram capability of the CRDM with an uncooled stator. A secondary test objective was to obtain a time versus temperature curve for an uncooled stator with either the two-phase or three-phase windings energized.

During the test, the CRDM was successfully scrammed with no anomalies in both the two-phase and three-phase stator winding energized hold conditions, after the respective equilibrium stator temperature had been obtained. Stator temperature stabilized at $2775^{\circ} \mathrm{F}$ and $2940^{\circ} \mathrm{F}$ for the two-phase and three-phase hold conditions, respectively. The time versus temperature curves obtained during the tests are presented in Figures 1 and 2. (Note: Because this report is short, all figures are grouped at the back of the report.)

Post-test operation of the stator and post-test electrical resistance measurements indicated that the damage to the stator was limited to minor damage to the stator winding insulation. Several reed switch connections on the position detector assembly had loosened, but since stator temperatures were above the reed switch solder melting temperature, failure of the reed switch connections was expected.

\section{INTRODUCTION}

In the Fast Flux Test Facility (FFTF) nine Control Rod Drive Mechanisms (CRDM's) are installed on the Fast Test Reactor (FTR) to lift, lower, or 
hold the reactor control rods. Reactivity is controlled by axially positioning the control rods within the active core in response to signals from an electrical control system. When the CRDM's are deenergized, the control rods drop to their lowest (least reactive) position. When the CRDM is energized, the control rods may be lifted to achieve criticality.

All the primary and secondary control rods have a common manifold which provides nitrogen cooling for the stator windings of the CROM's. A failure of the manifold or supply system could result in loss of coolant to any one or to all nine of the active CRDM's. A failure of this type is most unlikely. However, to demonstrate that such a failure would not prevent the safe shutdown of the reactor, the stator loss of coolant test was performed on the lead unit CRDM that was being used in the control rod system maintenance tests underway in the High Temperature Sodium Facility (HTSF) at HEDL.

The primary purpose of the test was to confirm that the CRDM could be successfully scrammed should an abnormal condition occur which would result in a loss of coolant to the stator windings. Scram capability was to be confirmed with the stator windings energized in the two-phase or three-phase positions. A secondary objective of the test was to obtain a time versus stator winding temperature curve for the uncooled stator.

This report describes and presents the results of the stator loss of coolant tests conducted at HEDL.

\section{DISCUSSION OF TEST}

\section{A. DESCRIPTION OF TEST EQUIPMENT}

To conduct the stator loss of coolant test, two primary pieces of hardware were needed; the Control Rod Drive Mechanism (CRDM) and a control console to energize the CRDM stator. Brief descriptions of the hardware and instrumentation used in the test follow. 


\section{CRDM}

The refurbished lead unit CRDM assembly, Figure 3, which had been life tested by the vendor, was used for the test. The assembly consisted of the stator jacket assembly, the motor tube rotor assembly, the position indicator housing, position indicator coil assembly, and the lower CRDM assembly. All the above units had been refurbished and used in the control rod system in-air maintenance demonstration tests conducted in HTSF.

The CRDM is used to position selected control rods in or out of the active core in response to signals from the electrical control system. The CRDM is capable of four modes of operation, i.e., latch, run, hold and scram. Latching is accomplished by creating a magnetic field around the segment arms at the upper end of the rotor assembiy. The field draws the upper end of the segment arms outward, driving the lower end inward, causing the roller nuts at the lower end to engage with the threads of the leadscrew.

When current is applied to the motor phases in a programmed sequence, the rotor assembly rotates and the leadscrew and control rod is translated in either the in or out direction depending on the sequence of the applied pulses. In the "hold" mode, the rotor does not rotate, but the segment arms are held latched by the stationary magnetic field, thus maintaining the leadscrew at any position in the stroke. When stator power is interrupted, the segment arm springs force the lower end of the segment arms outward, releasing the leadscrew and allowing it to travel to the full in position. Scram is initiated by removing the electrical power to the stator.

The stator-jacket assembly, which was the primary subassembly being tested, consists of an electrical stator surrounded by a stator cooling jacket, a stator outer shell and a stator end cover. The stator assembly and rotor assembly form a 4-pole, 6-phase, reluctancetype stepping motor, in which the rotor poles tend to maintain alignment with a stepwise rotating stator field. The six phases of the 
stator windings are arranged in a 4-pole motor configuration. The phases are identified as $A, B, C, A A, B B$, and $C C$ and are energized with direct current in a two-phase, three-phase sequence. The sequence is reversed to drive the CRDM leadscrew in the opposite direction.

\section{CRDM Controller Maintenance Console Assembly}

The control console used for the test consisted of the CRDM Controller Maintenance Console Assembly, Figure 4, which was designed to functionally test the CRDM primary Controller System controller drawers and the Relative Rod Position Indicator (RRPI) and Absolute Rod Position Indicator (ARPI) modules. Normally, the maintenance console is used with a resistive dummy load to check out a particular controller drawer or module. In this case, the dummy load was replaced with the lead unit stator assembly and the proper controller drawer and position indication module were installed in the console to provide a fully operational control rod system.

The maintenance console is a two-bay mobile test cubicle which supplies the voltage and external signals needed to energize the modules under test. The console also monitors the outputs of the modules. Basically, the console represents one channel of the controller system, one channel of the RRPI system, and one channel of the ARPI system.

\section{Instrumentation}

Instrumentation for the stator thermocouples consisted of a 12-channel multipoint recorder with a range of 0 to $1000^{\circ} \mathrm{F}$. In operation, each channel was recorded at one-minute intervals, with 5 seconds between adjoining channels. A pyrometer (General Electric Model $\mathrm{FH}-1$ ), was used to record the stator housing surface temperatures. 


\section{B. DESCRIPTION OF TEST}

\section{Test Preparation -- CRDM Hardware}

In preparation for the subject test, the lead unit CRDM lower assembly extension shaft disconnect (ESD) was raised and blocked approximately 10 inches above its normal position when engaged with the Control Rod Disconnect Driveline (CRDD). This operation was performed to provide a positive stop for the extension shaft disconnect during the planned scram operations. The block was cushioned with soft rubber foam to reduce the impact of the ESD on the wooden block during a scram.

After installation of the motor tube, stator-jacket, and position indicator assemblies, the connecting of twelve thermocouples located in the CRDM stator windings was initiated. Since there were no records as to where the twenty-two thermocouples were positioned in the stator windings, or even whether these thermocouples were good, resistance measurements were first taken and recorded, as shown in Table 1. From these resistance measurements, twelve thermocouples were selected for measurement, four with high resistances, four with low resistances and four in between the extremes, so that the top, middle and bottom stator winding temperatures might be recorded. The actual thermocouples selected are also shown in Table 1.

\section{Test Preparation -- CRDM Controller Maintenance Console Assembly}

Since the CRDM controller maintenance console assembly had never been unpackaged after arrival from the vendor's plant, the console assembiy was shipped to HTSF, unpackaged, and inspected. In addition, a complete checkout of the console was performed, using the dummy resistive load to verify that the console was operational.

Following checkout of the console, the console was connected to the stator, as shown in Figure 5, for the test. The position indicator detector was also connected to the console to record rod position. 
TABLE 1

THERMOCOUPLE RESISTANCE MEASUREMENTS

AND RECORDER CHANNEL IDENTIFICATION

(IRON-CONSTANTAN THERMOCOUPLES)

Thermocouple Identification

1

2

3

4

5

6

7

8

19

11

12

13

14

15

16

17

18

19

20

21

22
Resistance

Measurements

(ohms)

2.66

3.82

2.31

2.70

Open

3.40

3.70

1.86

2.64

3.55

2.50

1.56

3.71

1.50

2.65

3.10

2.85

3.70

3.00

3.30

1.50

3.20
Recorder

Channel

5

12

6

9

4

3

11

2

7

10

8

1 


\section{TEST OPERATIONS}

\section{Prel iminary Scram Test}

The initial test consisted of verifying that the CRDM mechanical and electrical components were operationally sound by performing an in-air scram test. This was accomplished by setting the motor phase voltage at 237 volts and latching the CRDM leadscrew. Then the motor phase voltage was reduced to 194 volts and the CRDM extension shaft raised six inches. Scram was then initiated and occurred as expected, with no hesitation or anomalies noted. The stator winding temperatures were recorded during the sequence and are presented in Table 2 and Figure 6 .

Note that thermocouples on recorder channels 3,7 , and 8 were selected for most of the temperature vs time plots. Channel 3 was selected since this particular thermocouple, along with channel 9, appeared to be located in the nitrogen cooling exit nozzle. Both channels were considerably lower in temperature and more sensitive to nitrogen coolant flows than the other channels. The other two selected channels, 7 and 8, were picked to represent the high and low extremes of the remaining temperature parameters. Temperatures on recorder channels 4,5 and 6 and 10,11 and 12 were observed to be normally grouped together between channels 7 and 8 . Channel 1 was essentially the same as channel 7 .

\section{Two-Phase Hold Test}

Following the successful prel iminary scram, the CRDM leadscrew was again latched and raised six inches. At this point, the console HOLD button was energized with the phase sequence in the two-phase position. This condition was then maintained $23-1 / 2$ hours until the stator winding temperatures were essentially stabilized at approximately $775^{\circ} \mathrm{F}$. Scram was then initiated and successfully completed. During scram, the position indicator went from 20.5 inches to 37.5 inches, indicating an open circuit and probable failure of the Position 
TABLE 2

TEMPERATURE READINGS $\left({ }^{\circ} \mathrm{F}\right)$ FOR CRDM STATOR 2-PHASE HOLD TEST

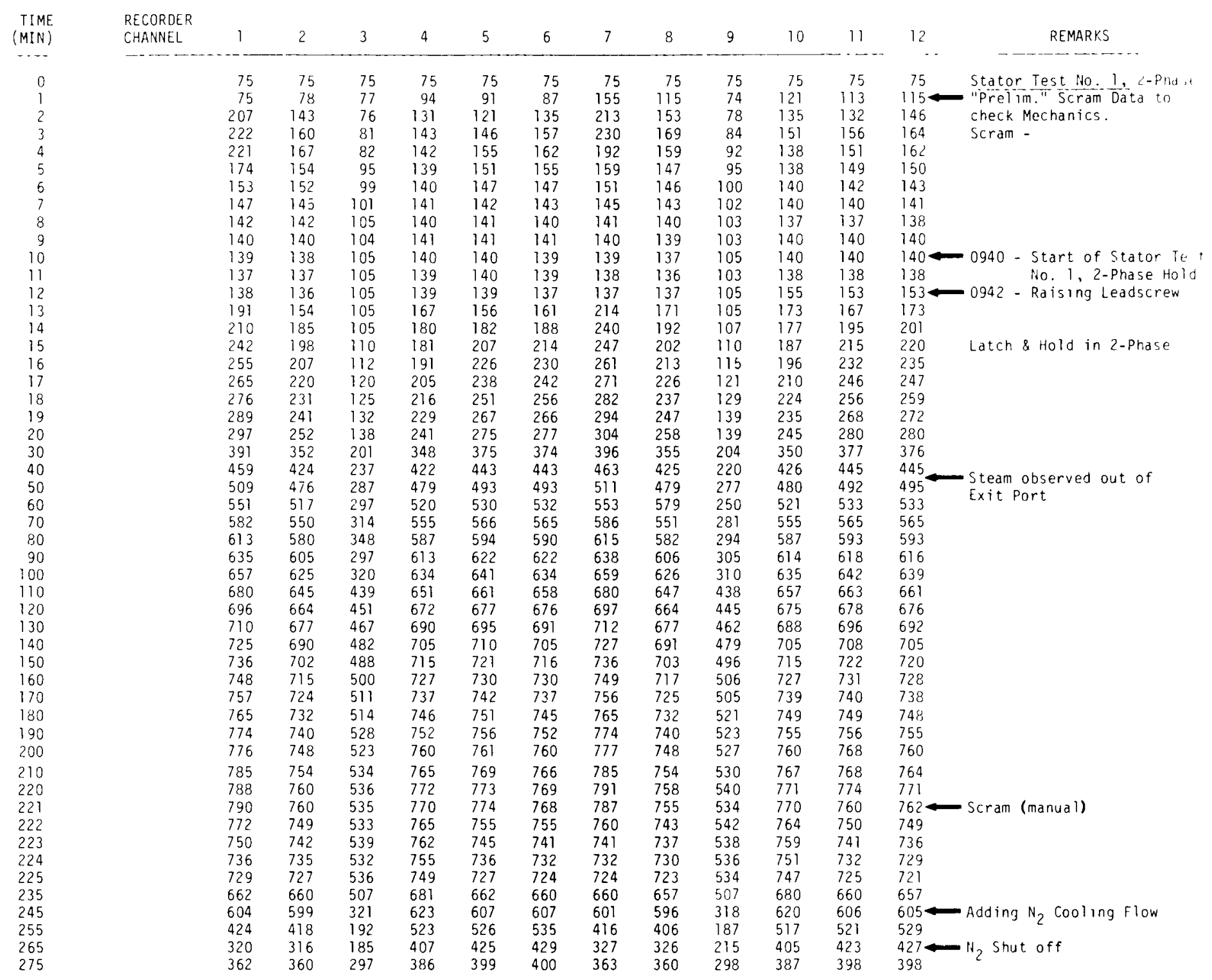


Indicator (P.I.) detector reed switch circuit. Therefore, the position indicator module was shut off for the remaining tests. Damage to the P.I. detector was later confirmed when the P.I. detector was removed for examination.

Nitrogen cooling was introduced into the stator upon completion of the test to cool the winding temperatures and hardware for the next test. Up to this point, only vapor had been observed leaving the stator exit nitrogen port and the off-gassing was attributed to drying of the stator windings. Upon introduction of the nitrogen cooling, after scram, a white smoke was observed billowing from the stator coolant exit port. The smoke had a distinct odor and was recognized to be from the stator winding insulation. Velocity of the nitrogen gas was minimized to prevent possible damage to the winding insulation due to the gas flow.

Table 2 and Figure 1 present the temperature data obtained during the two-phase hold test. Table 2 1ists the temperatures recorded for all recorder channels and Figure 1 presents a temperature vs time plot for channels 3,7 and 8 . Variations in the channel 3 temperature vs time plot early in the test are attributed to vapor off-gassing, thereby intermittently cooling the thermocouples in the nitrogen cooling exit. Nitrogen cooling of the stator following scram was significant in reducing stator winding temperatures.

Figure 7 presents the current and voltage for the energized phases $B$ and $C$ vs time. Note that six stator phase windings exist; they are identified as $A, B, C, A A, B B$, and $C C$. Currents to the phase $B$ and $C$ windings were not reduced below 5.2 amps and the neutral current was not reduced below 10.9 amps as the stator was heated. Voltage increased slightly as the amperage was reduced. 


\section{Three-Phase Hold Test}

Relatch of the CRDM leadscrew for the three-phase hold test was attempted at various temperatures as the stator cooled to determine the highest temperatures at which the relatch could be obtained. Relatch was attempted at average stator winding temperatures of $400^{\circ} \mathrm{F}$, $350^{\circ} \mathrm{F}, 325^{\circ} \mathrm{F}$, and $300^{\circ} \mathrm{F}$. Relatch was not successfully obtained until the $300^{\circ} \mathrm{F}$ temperature was obtained.

Once relatch was obtained, the CRDM leadscrew and disconnect assembly was raised six inches, and the HOLD button energized with the phase sequence in the three-phase position. This condition was maintained for approximately 2-1/2 hours until the average stator winding temperature had essentially stabilized at $940^{\circ} \mathrm{F}$. At this point, scram was again initiated and successfully completed with no hesitation or other anomalies. Cool-down of the stator assembly was accomplished normally without the introduction of nitrogen cooling.

Table 3 and Figure 2 present the temperature data obtained during the three-phase hold test. The effect of latching and nitrogen cooling on the stator temperatures can be observed in the early portion of the test in Figure 2. The 15-minute to 25-minute time period is shown in greater detail in Figure 8 to better show the relationship between the different temperature parameters during one of the latch attempts. Figure 9 presents the current and voltage for the energized phases $A, B$, and CC vs time for the three-phase hold test. Current to each phase decreased to $\sim 4.9$ amps and the neutral current decreased to 214.9 amps as the stator was heated to a temperature of $\sim 940^{\circ} \mathrm{F}$. Voltage increased slightly as the currents decreased.

During both the two-phase and three-phase hold tests, the external CRDM surface temperatures were monitored using a dual range pyrometer. These temperatures and location of measurements are shown in Table 4. 
TABLE 3

TEMPERATURE READINGS $\left({ }^{\circ} \mathrm{F}\right)$ FOR CRDM STATOR 3-PHASE HOLD TEST

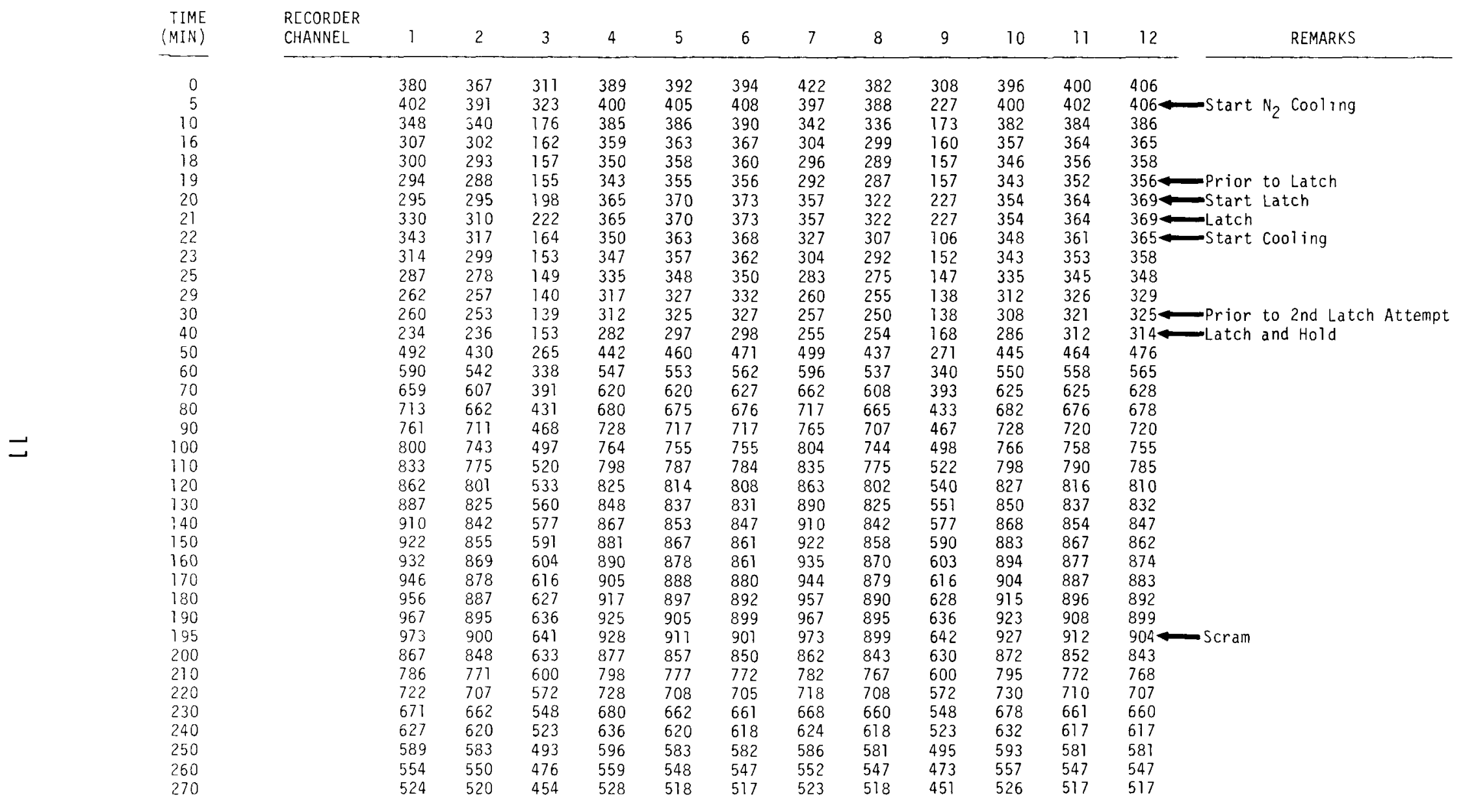


TABLE 4

\section{CRDM EXTERNAL TEMPERATURES $\left({ }^{\circ} \mathrm{F}\right)$ DURING STATOR LOSS OF COOLANT TESTS}

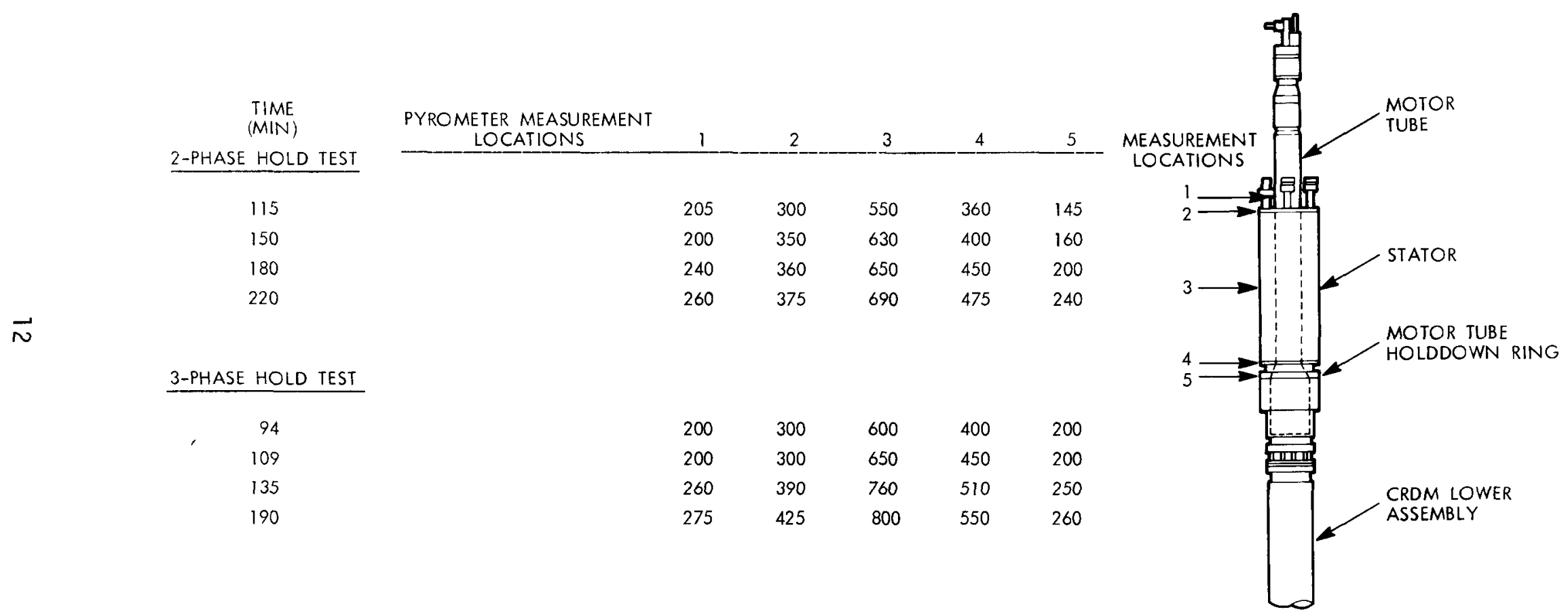

HEDL $7704-086.2$ 


\section{Post-Test Verification Tests}

As a post-test inspection and equipment verification, the stator insulation resistance was checked and CRDM Teadscrew assembly was cycled. The leadscrew was cycled 12 times over a six-inch distance while maintaining the average stator temperature below $500^{\circ} \mathrm{F}$ with nitrogen cooling. At the end of 12 cycles, the CRDM was successfully scrammed with no anomalies noted during the scram or cycling operation. The insulation resistance was measured at 100 Megohms before and after the leadscrew cycling and scram, indicating that there was no significant degradation of the insulation during the stator loss of coolant tests or the post-test inspection.

Table 5 and Figure 10 present the stator temperature vs time data obtained during the post-test CRDM leadscrew cycling test. Although nitrogen cooling was being applied (amount of flow unmeasured), the flow was too low to remove the heat being generated in the stator and a gradual heatup of the stator occurred until scram was initiated.

Upon completion of the testing and post-test operations, the position detector assembly was removed for inspection to determine what damage had occurred when the unit was subjected to the elevated temperatures and scram operations during the stator loss of coolant tests. During the two-phase hold test, the position indication detector system failed, indicating an open circuit. The position indicator module was not used after the failure. When inspected after disassembly, the resistor ladders were intact, but some reed switches were no longer attached to the ladder (see Figures 11 and 12). The ladders operated satisfactorily with the missing reed switches when attached to the position indicator module and actuated by a magnet. The open circuit indication in the two-phase hold test scram was not explained.

Following the examination of the position indicator, the CRDM stator and motor tube were removed for examination. As observed in 
TABLE 5

CRDM STATOR TEMPERATURES $\left({ }^{\circ} \mathrm{F}\right)$ DURING CRDM LEADSCREW CYCLE TEST

\begin{tabular}{|c|c|c|c|c|c|c|c|c|c|c|c|c|c|}
\hline $\begin{array}{l}\text { TIME } \\
\text { (MIN) }\end{array}$ & $\begin{array}{l}\text { RECORDER } \\
\text { CHANNEL }\end{array}$ & 1 & 2 & 3 & 4 & 5 & 6 & 7 & 8 & 9 & 10 & 11 & 12 \\
\hline 0 & & 75 & 75 & 75 & 75 & 75 & 75 & 75 & 75 & 75 & 75 & 75 & 75 \\
\hline 3 & & 239 & 151 & 78 & 137 & 143 & 148 & 253 & 163 & 81 & 146 & 155 & 162 \\
\hline 6 & & 272 & 195 & 99 & 177 & 207 & 210 & 287 & 205 & 100 & 188 & 211 & 217 \\
\hline 9 & & 334 & 250 & 115 & 234 & 250 & 255 & 337 & 257 & 117 & 242 & 255 & 263 \\
\hline 12 & & 371 & 293 & 137 & 279 & 292 & 297 & 375 & 300 & 140 & 287 & 297 & 303 \\
\hline 15 & & 401 & 328 & 157 & 321 & 328 & 332 & 407 & 334 & 158 & 326 & 334 & 338 \\
\hline 18 & & 430 & 362 & 176 & 357 & 362 & 363 & 435 & 365 & 177 & 362 & 365 & 368 \\
\hline 21 & & 457 & 390 & 193 & 388 & 390 & 392 & 460 & 393 & 196 & 392 & 396 & 397 \\
\hline 24 & & 478 & 416 & 217 & 417 & 417 & 418 & 483 & 418 & 212 & 420 & 400 & 422 \\
\hline 27 & & 502 & 440 & 228 & 442 & 442 & 442 & 505 & 443 & 231 & 447 & 444 & 444 \\
\hline 30 & & 522 & 462 & 247 & 466 & 463 & 462 & 526 & 465 & 247 & 468 & 465 & 466 \\
\hline 33 & & 455 & 442 & 257 & 454 & 445 & 444 & 445 & 437 & 258 & 453 & 442 & 440 \\
\hline 36 & & 425 & 422 & 263 & 443 & 430 & 425 & 422 & 419 & 262 & 440 & 427 & 421 \\
\hline \multicolumn{14}{|c|}{$\begin{array}{l}\text { CRDM Leadscrew cycled in and out in } 6 \text {-inch strokes for } \\
12 \text { complete cycles over a period of }+6 \text { minutes to } \\
+27 \text { minutes. Scram was actuated at }+31 \text { minutes. }\end{array}$} \\
\hline
\end{tabular}


Figures 13 through 15, both units were discolored due to the $940+^{\circ} \mathrm{F}$ temperatures and some deterioration of winding insulation is apparent by observing the condition of the stator windings and external surfaces of the motor tube.

\section{CONCLUSIONS}

The completion of the CRDM stator loss of coolant test verified that the CRDM could be scrammed without difficulty when a loss of nitrogen cooling occurred and the stator winding energizing sequence was in either the two-phase or three-phase hold condition. With loss of coolant, the stator winding temperatures increased steadily in both the two-phase and three-phase hold conditions until the equilibrium temperatures were obtained -- $\sim 775^{\circ} \mathrm{F}$ for the two-phase hold condition and $2940^{\circ} \mathrm{F}$ for the three-phase hold condition. Scram was successfully demonstrated in both cases after the static windings had reached the respective equilibrium temperature. Stator phase currents did not reduce to a value low enough during stator heat-up to cause inadvertent unlatching of the control rod.

Post-test operation of the stator and post-test electrical resistance measurements indicated that the damage to the stator was limited to minor stator winding insulation damage. Loosening of several reed switch connections on the position detector assembly had occurred, but since stator temperatures were above the reed switch solder melting temperature, failure of the reed switch connections was expected. 


\section{ACKNOWLEDGEMENTS}

The authors wish to acknowledge the following persons for their contribution to the success of this test program.
K. M. Beadell
W. F. Bisley
H. L. Anderson
J. C. Moore 


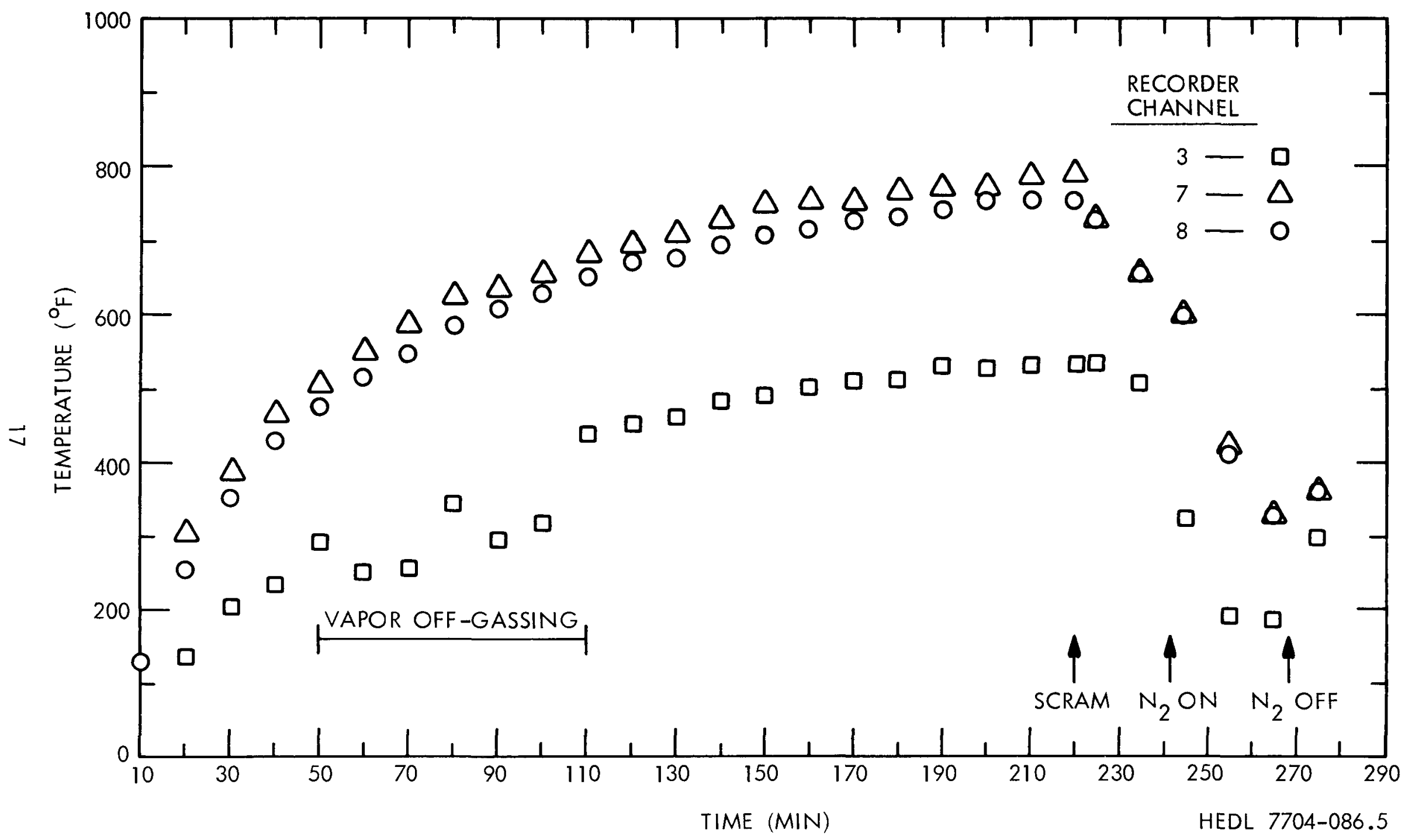

FIGURE 1. CRDM Stator Temperatures vs Time -- 2-Phase Hold. 


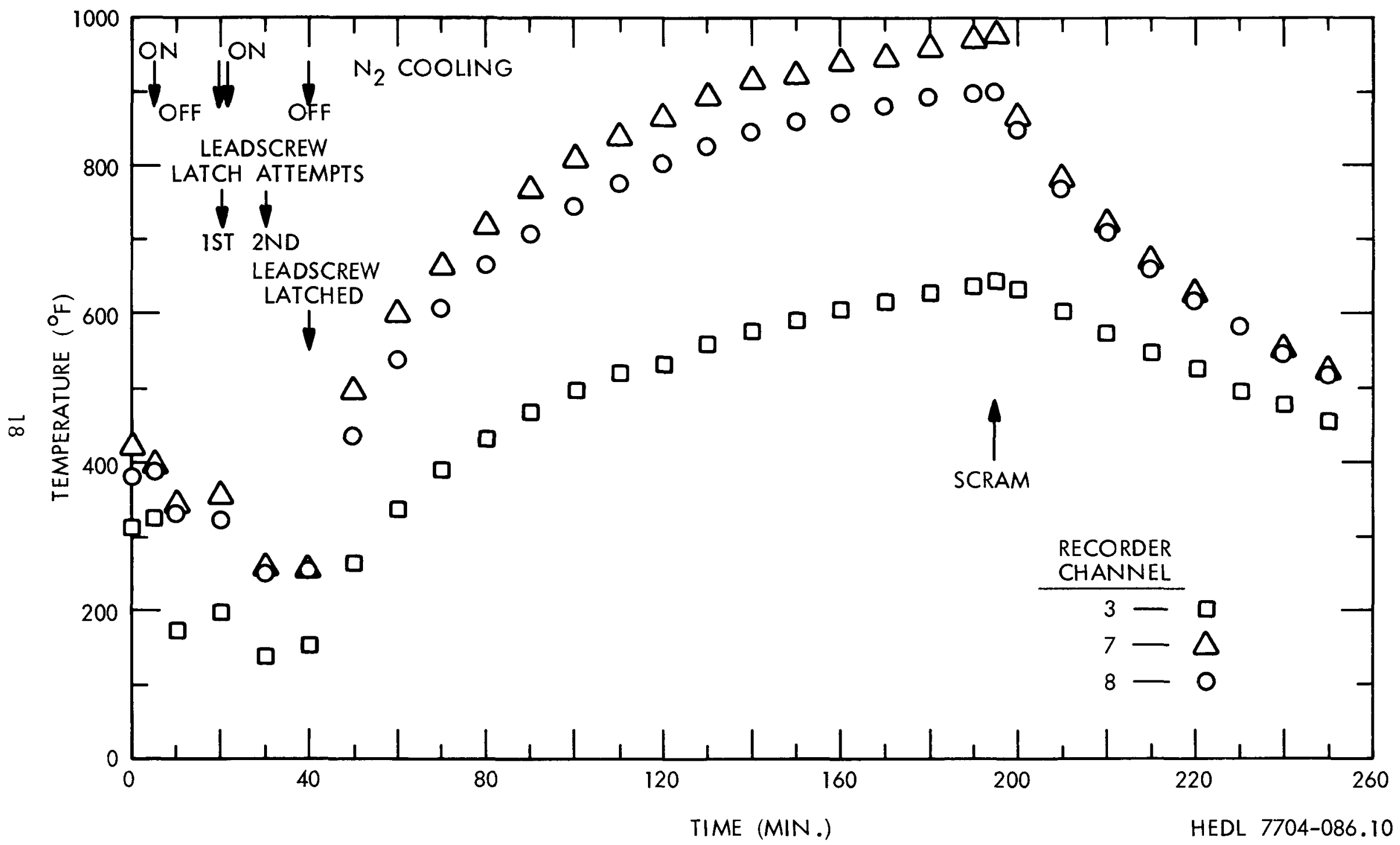

FIGURE 2. CRDM Stator Temperatures vs Time -- 3-Phase Hold. 


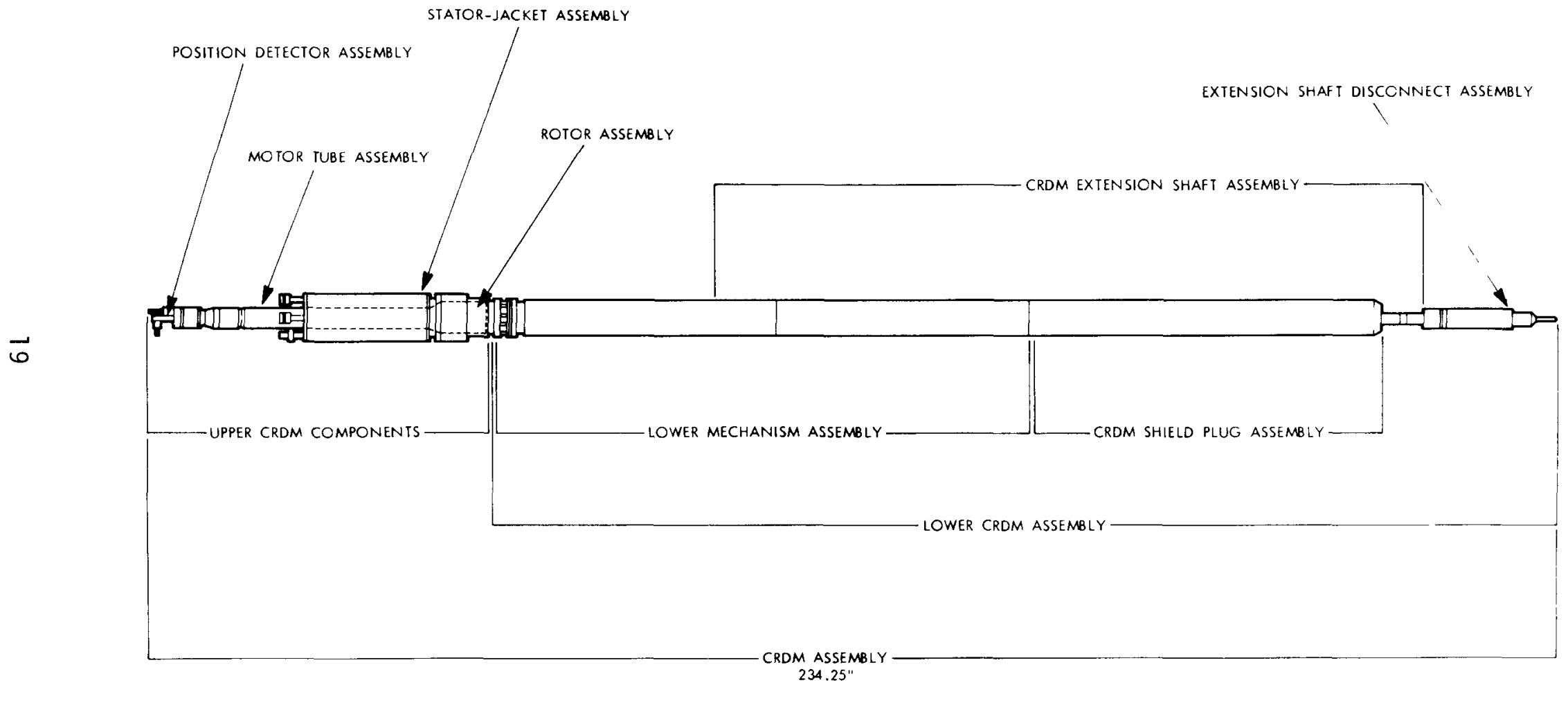

HEDL $7704-086.1$

FIGURE 3. Control Rod Drive Mechanism Configuration -- Nomenclature. 


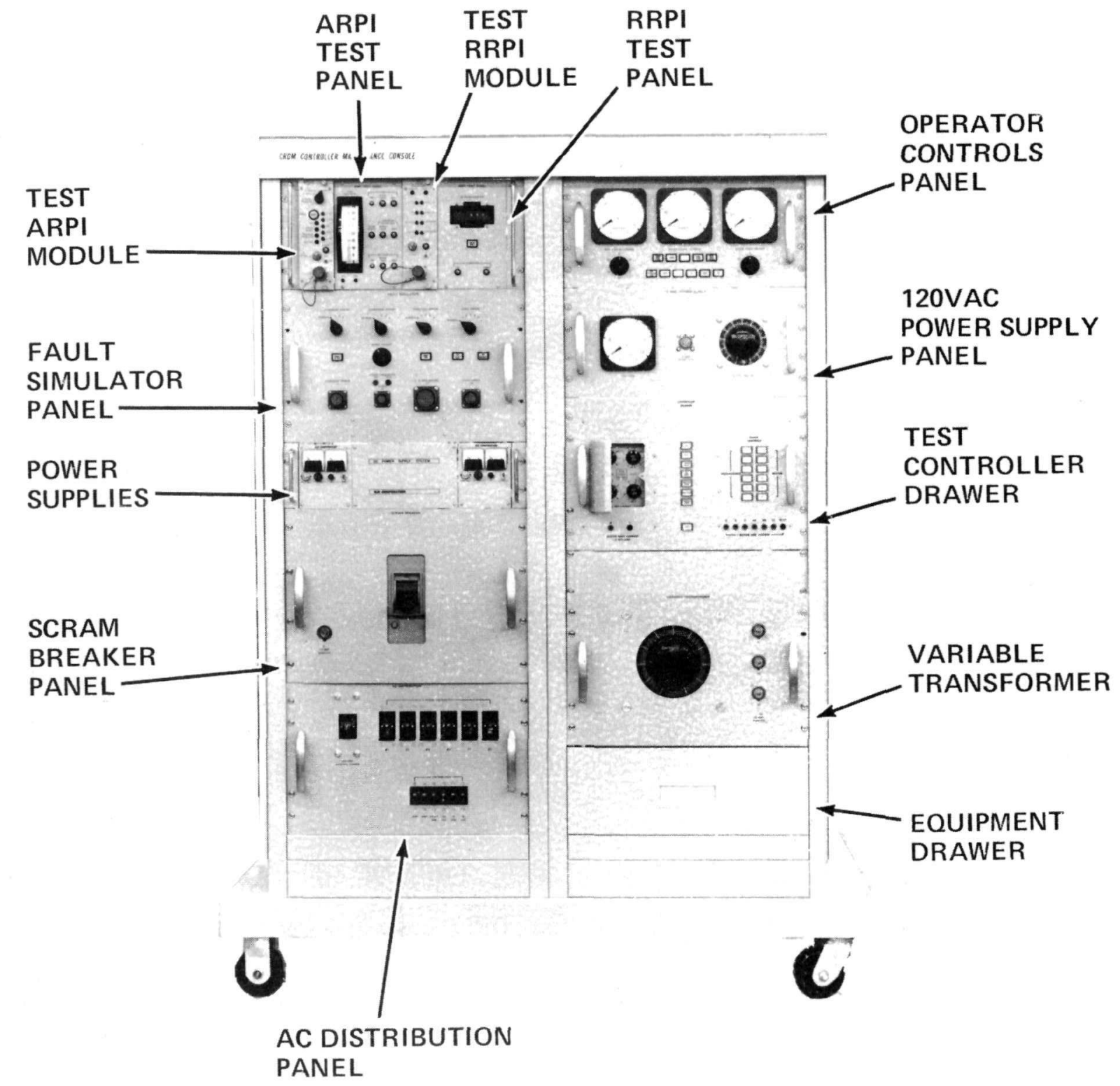

FIGURE 4. CRDM Controller Maintenance Console. 


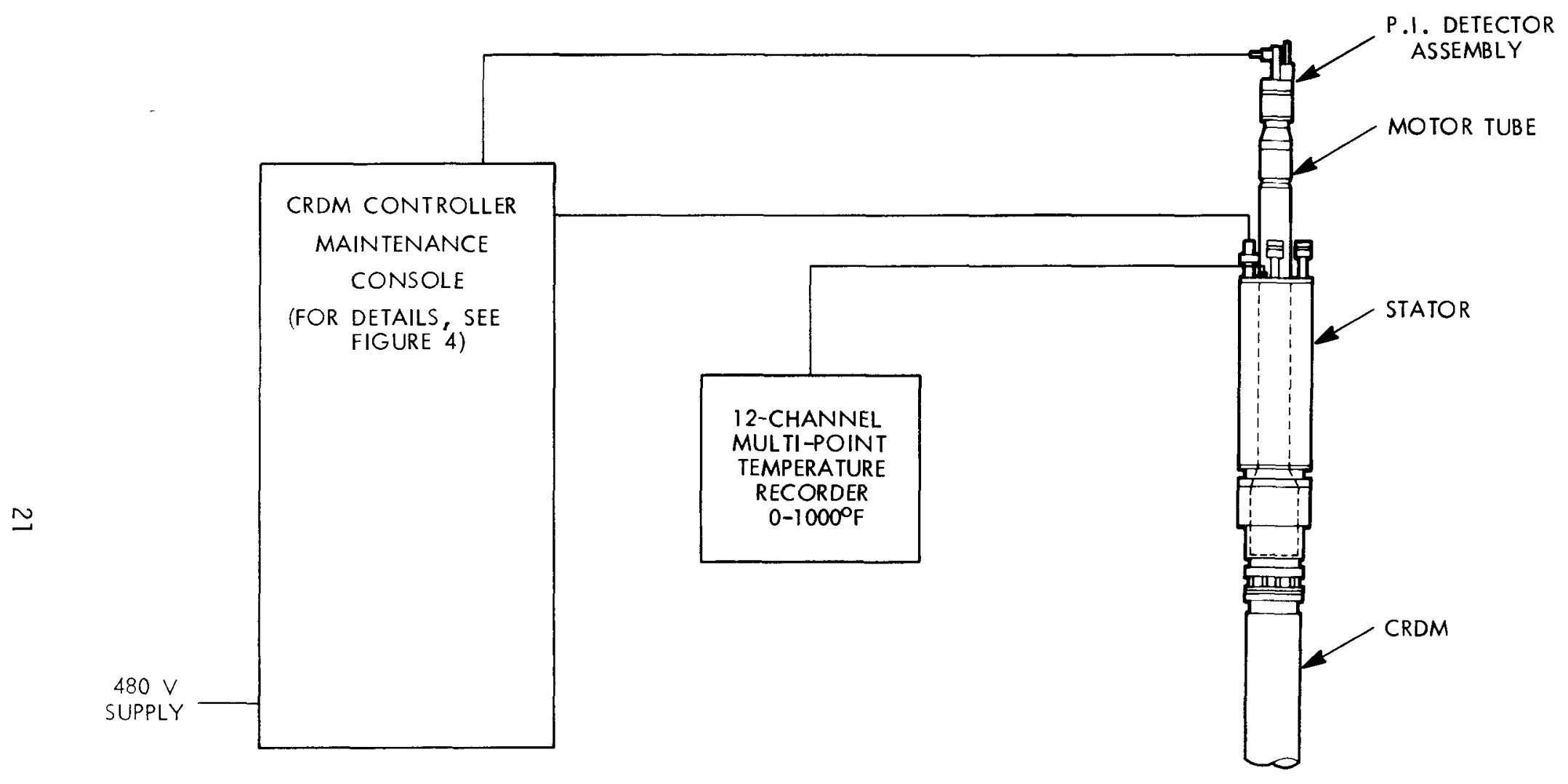

HEDL 7704-086.3

FIGURE 5. Stator Loss of Coolant Test Configuration. 


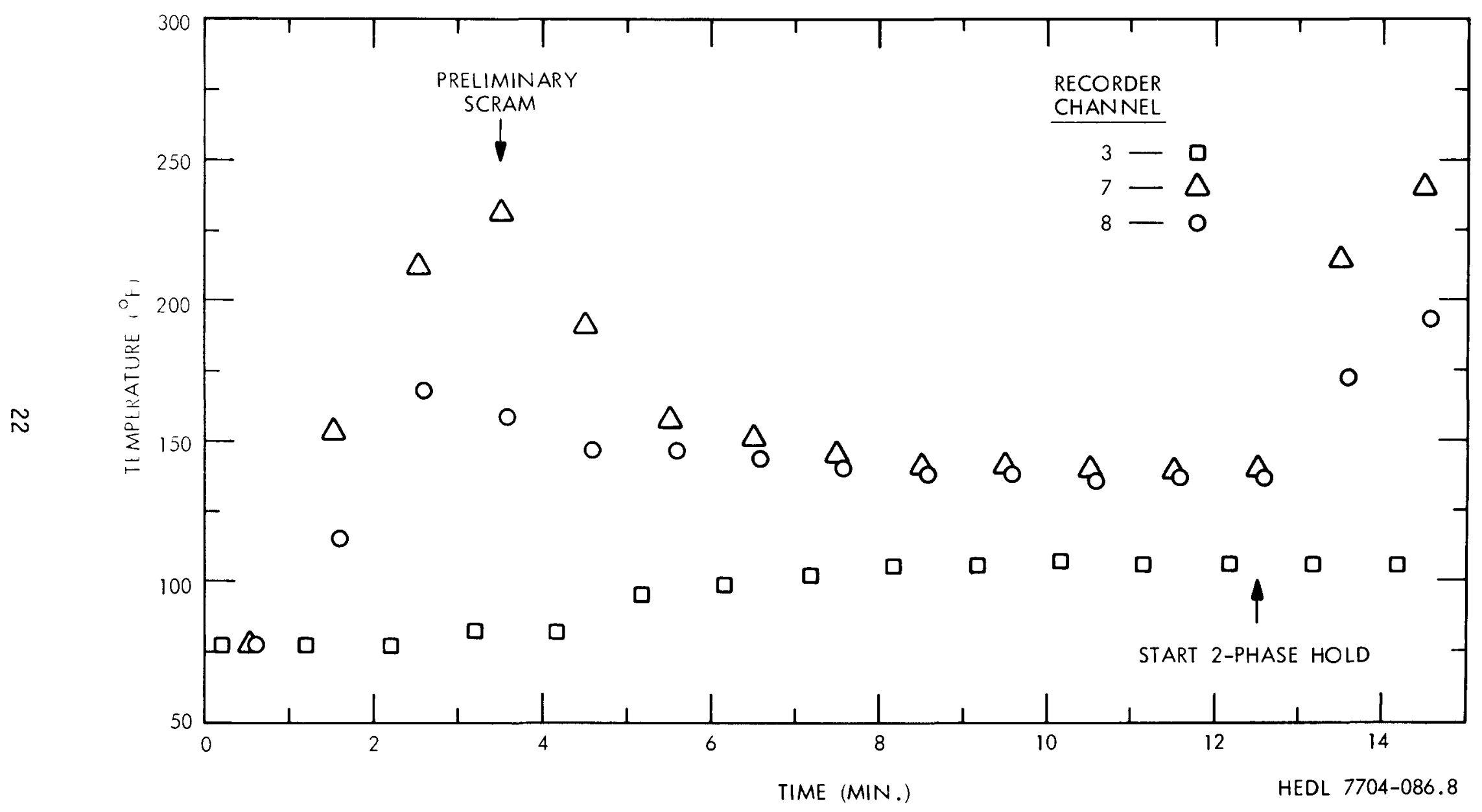

FIGURE 6. CRDM Stator Temperatures vs Time -- Preliminary Scram \& 2-Phase Hold. 


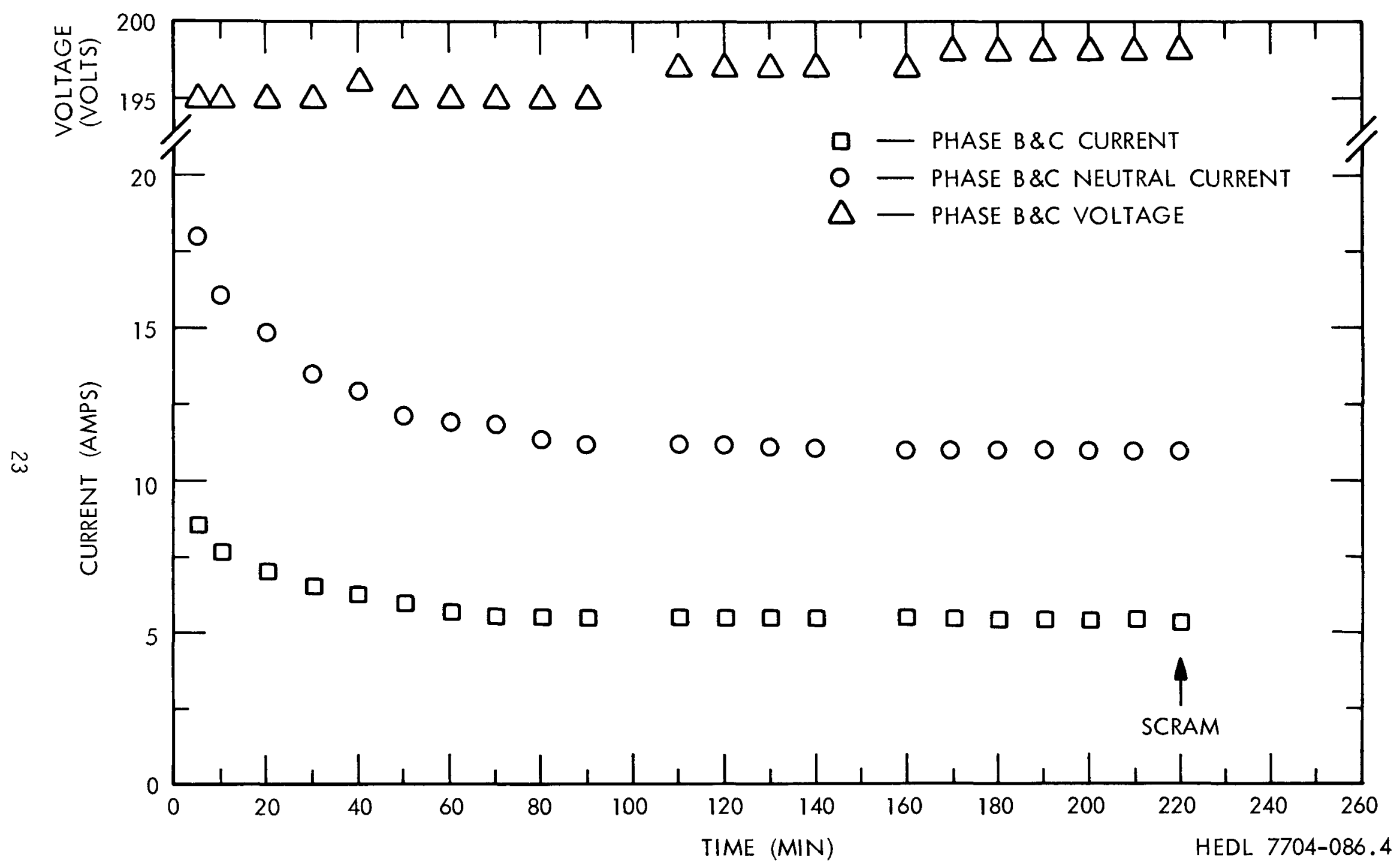

FIGURE 7. CRDM Stator 2-Phase Voltage \& Current vs Time. 


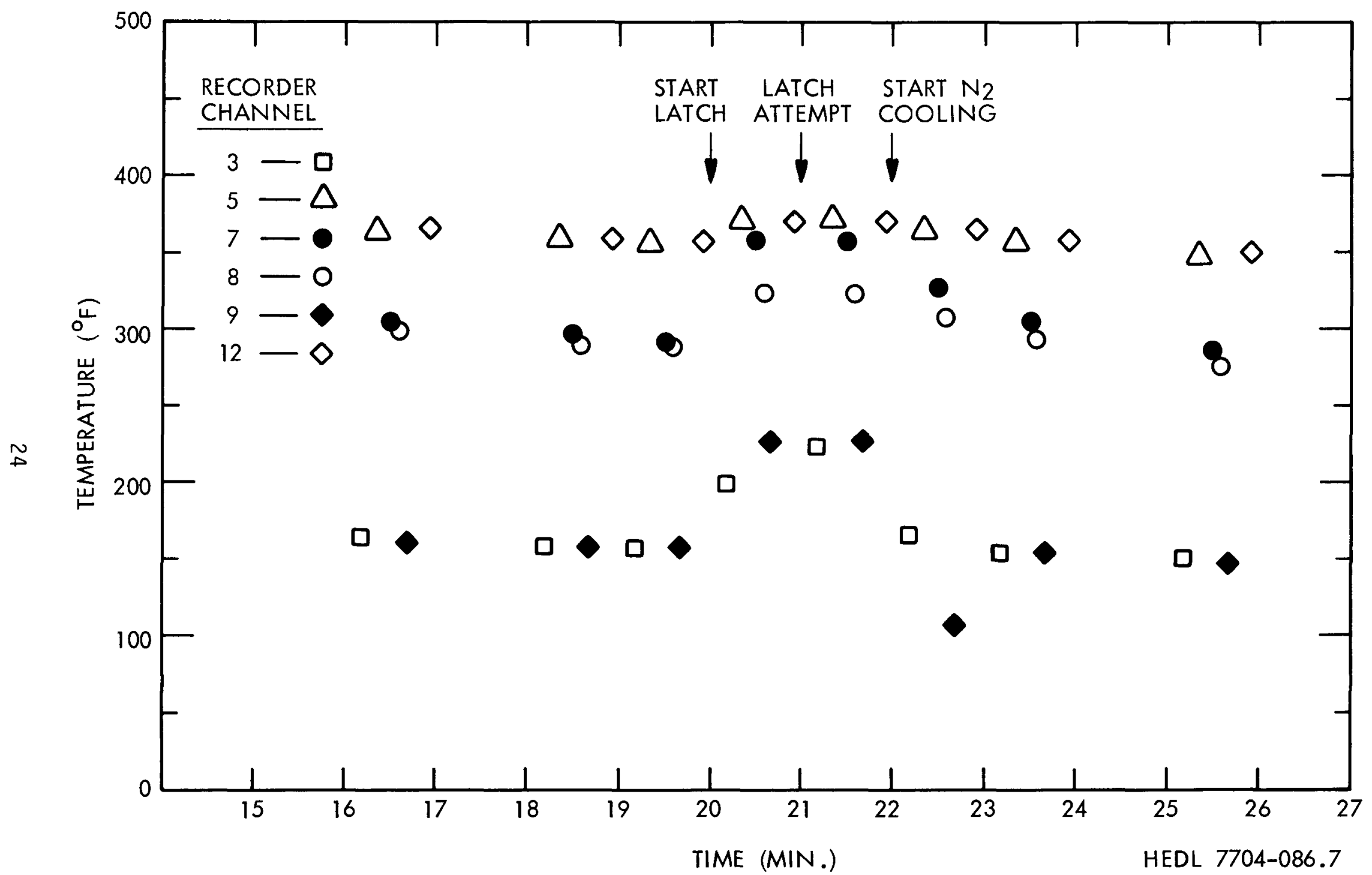

FIGURE 8. CRDM Stator Temperatures vs Time -- First Latch Attempt - 3-Phase Hold. 


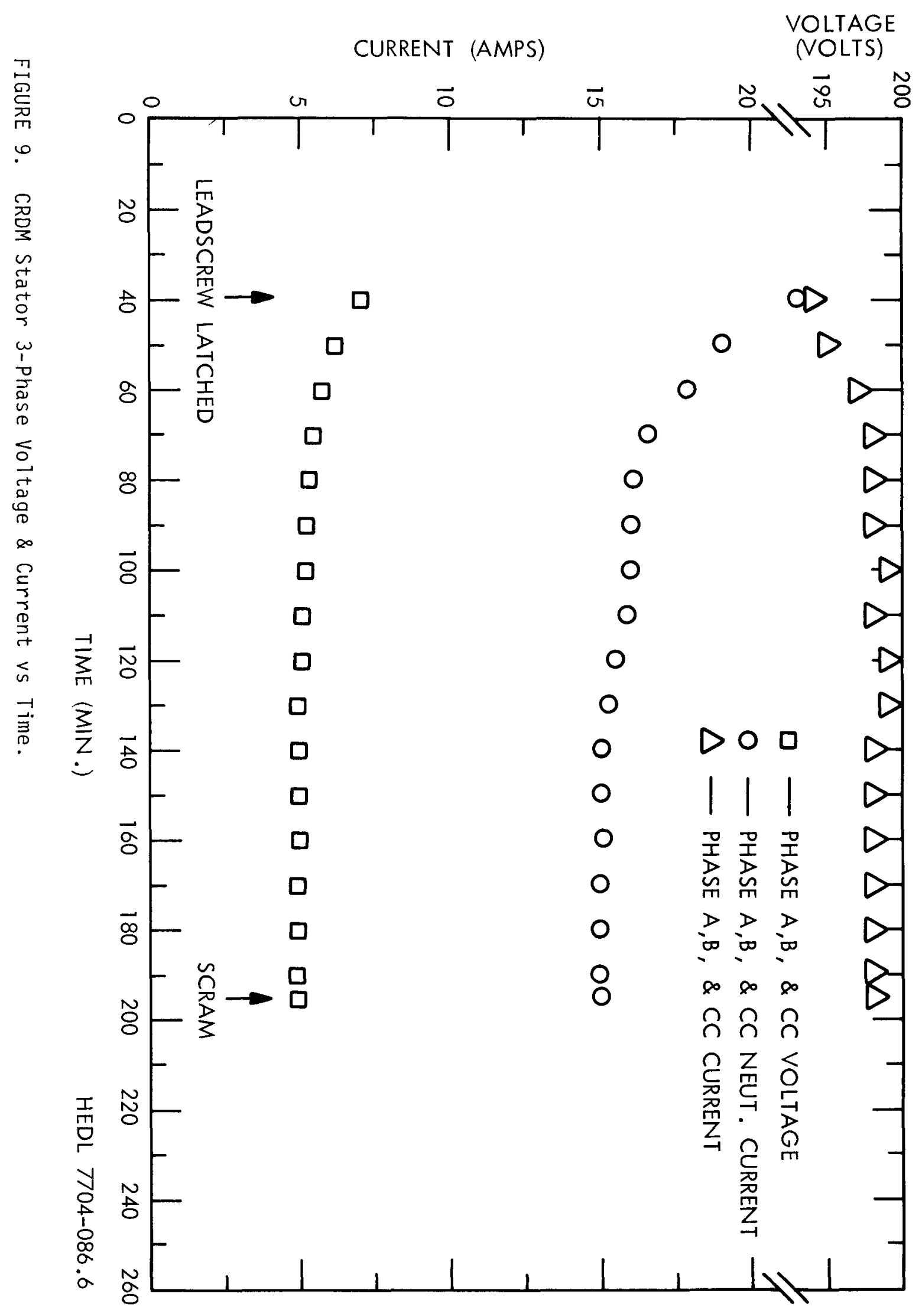




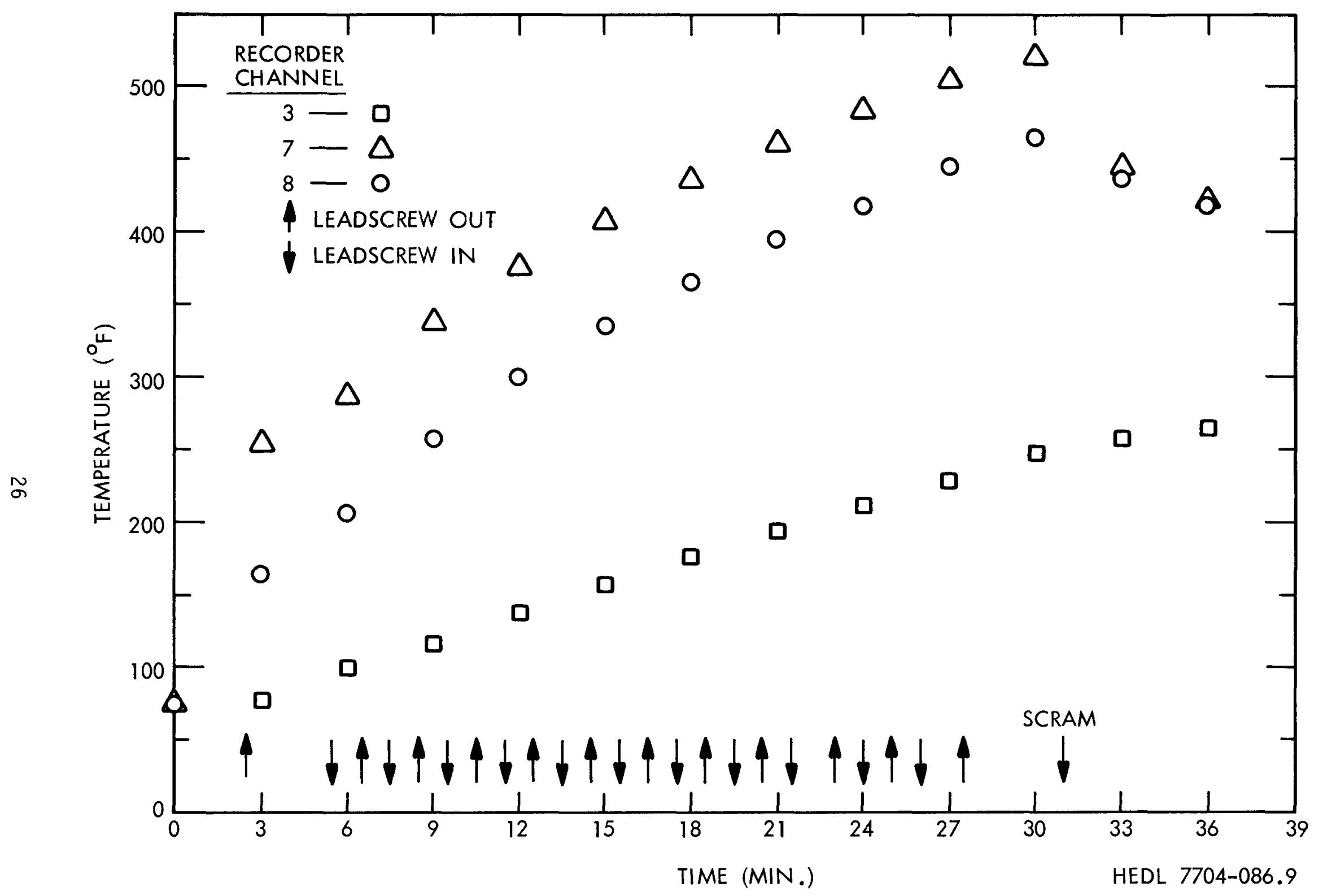

FIGURE 10. CRDM Stator Temperatures vs Time -- CRDM Leadscrew Cycle Test. 


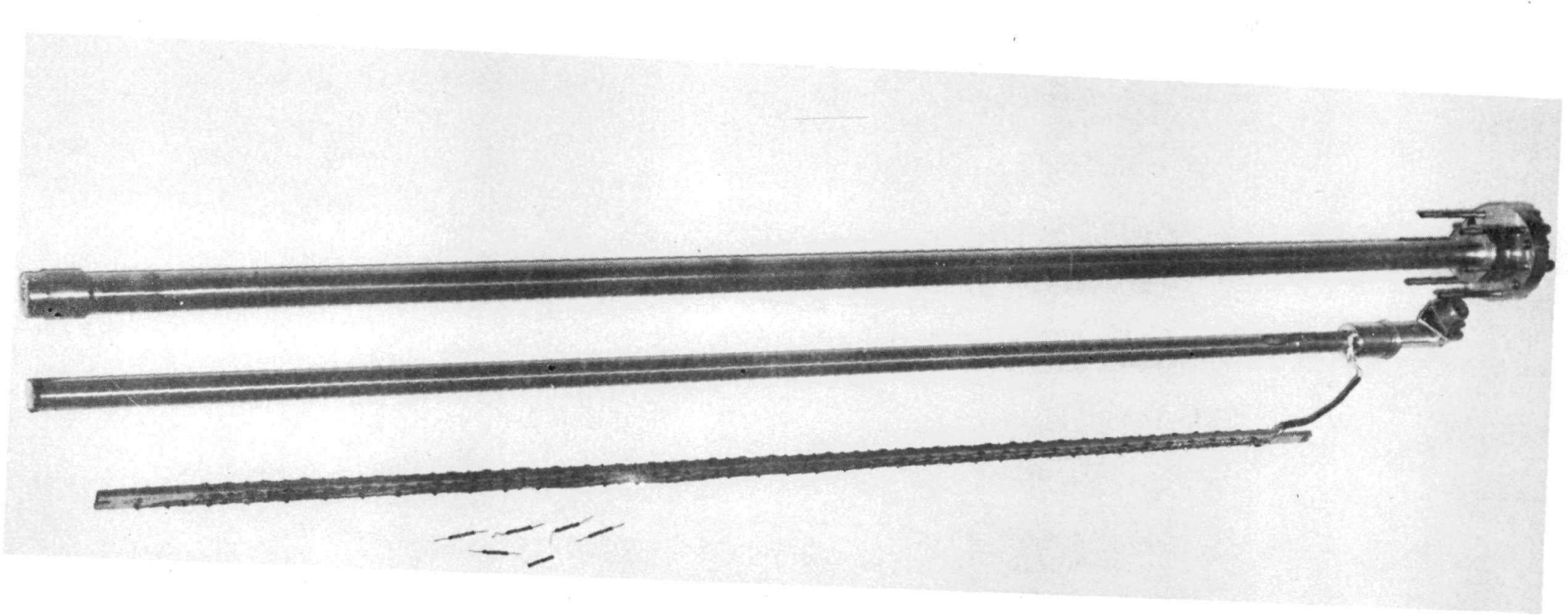

FIGURE 11. Position Detector Assembiy. 

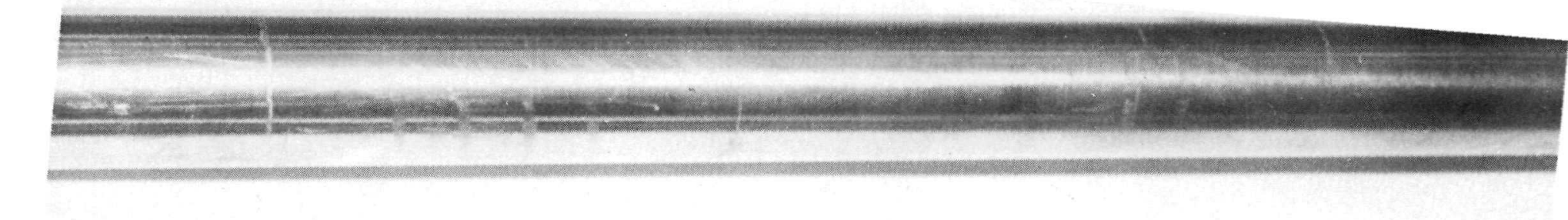

N

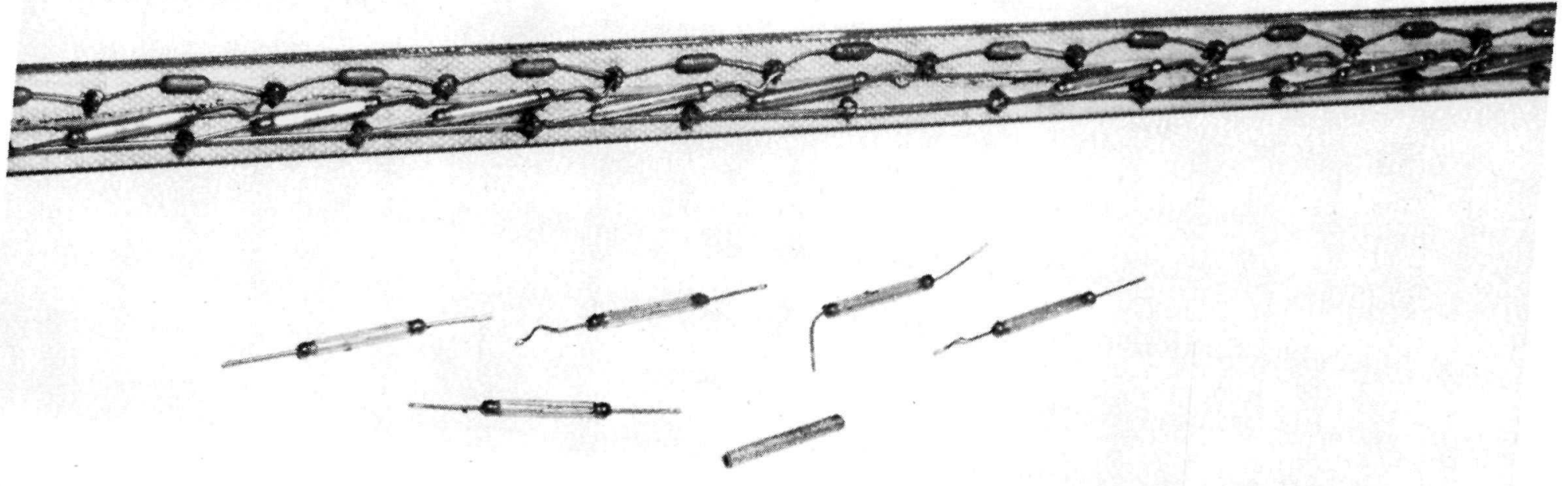

FIGURE 12. Position Detector Assembly.

Neg. No. $771940-4$ 

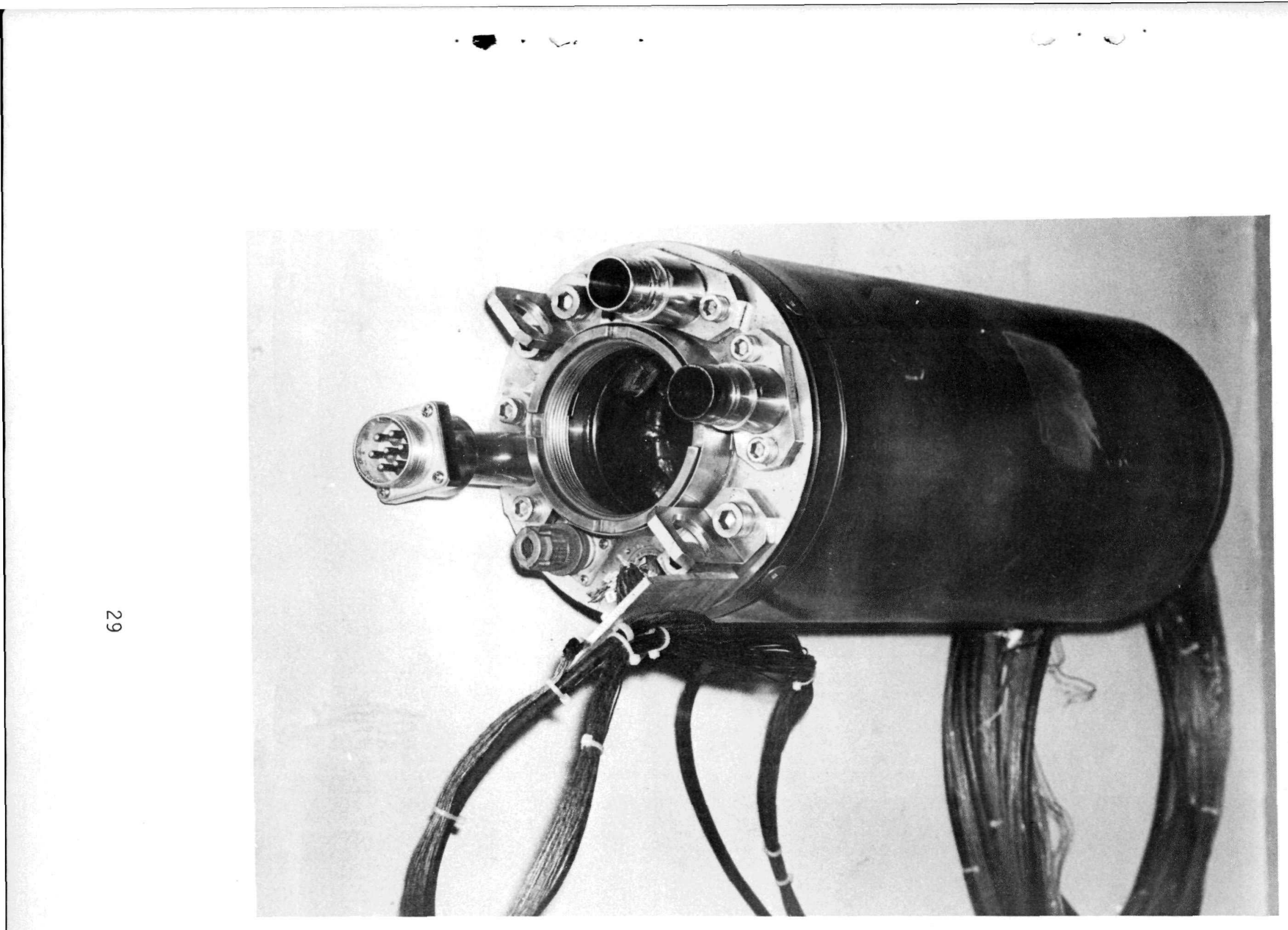

FIGURE 13. CRDM Stator Assembly.

Neg. No. 771918-11 


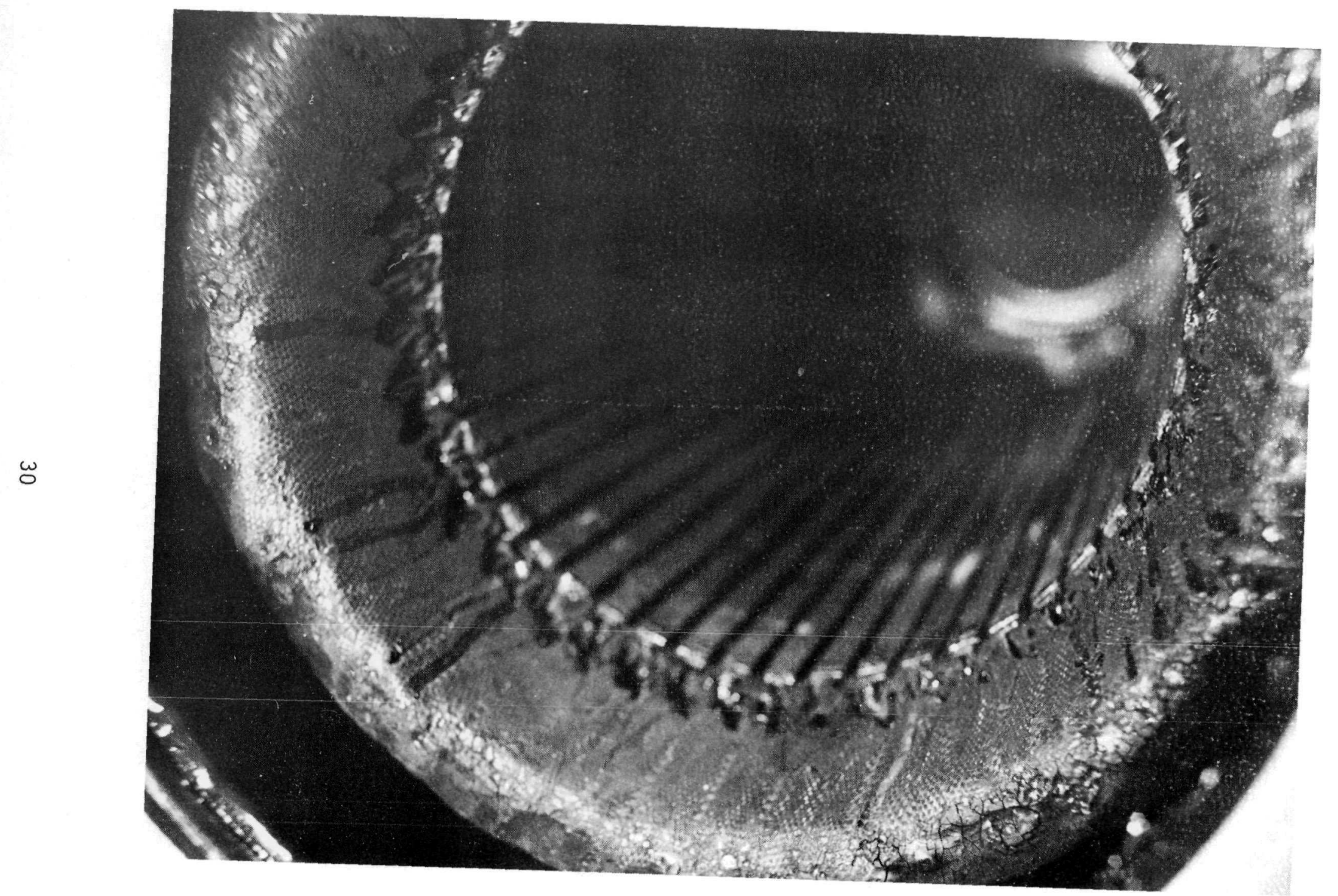

FIGURE 14. CRDM Stator Assembly.

Neg. No. 771918-1

- . . 


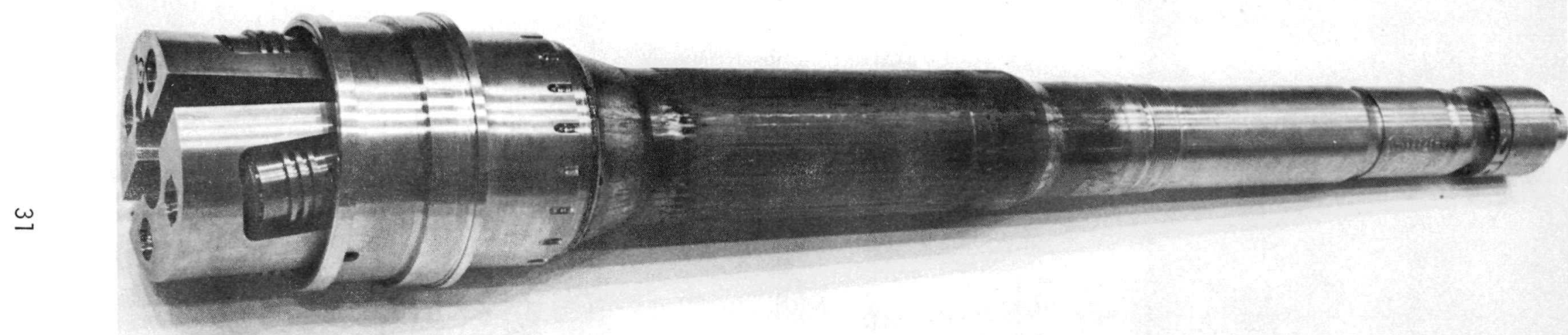

Neg. No. 771918-23

FIGURE 15. CRDM Motor Tube Assembly. 